\title{
Analysis of Increasing Political Representation Female Legislative Members in Regional People's Representative Assembly of Tanjungpinang City Period 2014 and 2019
}

\author{
Lince magriasti ${ }^{1}$ \\ $\left\{\right.$ lincemagriasti@fis.unp.ac.id $\left.{ }^{1}\right\}$ \\ Public Administration Department Of Social Science Faculty Of Universitas Negeri Padang
}

\begin{abstract}
The political representation of women in many regions in Indonesia does not meet the threshold for women's representation, including in the DPRD Kota Tanjungpinang. However, the quantity of women in the legislature has increased significantly in each election implementation since the area became the capital of the Riau Islands Province in 2002. Tanjungpinang City as a new autonomous region has no problems with women's electability in the legislature, although it still does not meet the threshold for women's representation. When the early Tanjungpinang City legislature was formed until the last implementation of the 2019 Election, women's political representation experienced an increase, especially seen from the electability level of incumbent candidates. There tend to be almost all female incumbent candidates in the previous period being re-elected in every election until the 2019 election. Tanjungpinang with the heterogeneity of the population is interesting to see the level of women's political representation so that it shows success not only in the legislative body but also succeeded in obtaining the deputy mayor of Tanjungpinang in the general election of 2018
\end{abstract}

Keywords: improvement, women's political representation, Tanjungpinang City

\section{Introduction}

The idealism of a democratic state in the life of a state and society is recognition, equality, and equality in various aspects of life. One of the inevitable aspects of people's life is the political aspect. In the political field, equality and commensurate can be represented through participation in the political process. This ultimately requires recognition and fairness in carrying out political participation. The level of community political participation will determine the success of a political system and the political system will gain legitimacy when the community provides support for any policies issued. Policies that have always been fought to ensure equality and justice in society, one of which is the affirmative action (affirmation) policy on women's representation in decision-making institutions such as legislative bodies. The importance of this affirmative policy is intended so that the treatment gap for marginalized groups can be reduced, a problem that often arises is the gender gap. Syafuan Rozi [1] in his writing said that the gender gap in politics is related to two things, first one, in the distribution 
of power and the next in decision making. This occurs at all levels of power including in determining the position of women in political institutions.

Sri Zul Chairiyah said that there are three things that become the basis for the importance of affirmative action policies, first, historical foundation. The discussion on the importance of increasing women's political repression is a long struggle that has been carried out since this country was colonized, and has even become the world's discussion. Second, the philosophical foundation. This foundation considers two aspects in Indonesia, namely the purpose of forming a state and fulfilling the basic principles of a democratic state. Third, a constitutional foundation based on the law as stipulated in the 1945 Constitution Article $28 \mathrm{H}$ paragraph 2 which states that "everyone has the right to receive special facilities and treatment to obtain equal opportunities and benefits in achieving equality and justice." [2] This implies that the Indonesian state supports the affirmative action policy because it relates to equal rights regardless of origin or gender.

One of the affirmative policies ratified in the Republic of Indonesia Law to ensure justice and equality of gender is the establishment of quotas for women's representation in the implementation of elections in Indonesia. The history of election administration in Indonesia has undergone major changes after the 1998 reform, especially since the enactment of a $30 \%$ quota for women's representation (sometimes used interchangeably with representation) in compiling lists of candidates for legislative members starting from the central level to regional levels in the 2004 General Elections. From 2014 till 2019, the provisions for women's quota in the Election Law have undergone several developments. This can be seen in the Election Law as can be seen in the following table: 
Table 1 The Development of Affirmative Policies in the Election Law in Indonesia from the 2004 Election to the 2019 Election

\begin{tabular}{|c|c|c|c|c|c|}
\hline No & Issue & 2004 Election & 2009 Election & 2014 Election & 2019 Election \\
\hline 1 & Policy & $\begin{array}{l}\text { UU Number } 12 \\
\text { of } 2003\end{array}$ & $\begin{array}{l}\text { UU Number } 10 \\
\text { of } 2008\end{array}$ & $\begin{array}{l}\text { UU Number } 8 \\
\text { of } 2012\end{array}$ & $\begin{array}{l}\text { UU Number } 7 \\
\text { of } 2017\end{array}$ \\
\hline 2 & $\begin{array}{l}\text { Regional } \\
\text { Election }\end{array}$ & $\begin{array}{l}\mathrm{DPR}=3-12 \text { chair } \\
\mathrm{DPRD}=3-12 \\
\text { chair }\end{array}$ & $\begin{array}{l}\mathrm{DPR}=3-12 \text { chair } \\
\mathrm{DPRD}=3-12 \\
\text { chair }\end{array}$ & $\begin{array}{l}\mathrm{DPR}=3-12 \\
\text { chair } \\
\text { DPRD=3-10 } \\
\text { chair }\end{array}$ & $\begin{array}{l}\mathrm{DPR}=3-12 \\
\text { chair } \\
\text { DPRD = 3-10 } \\
\text { chair }\end{array}$ \\
\hline & & $\begin{array}{l}\text { Article } 65 \\
\text { paragraph (1) } \\
\text { regarding the }\end{array}$ & $\begin{array}{l}\text { Article } 53 \\
\text { concerning the } \\
\text { quota of } 30 \% \text { of } \\
\text { women in the } \\
\text { candidate list }\end{array}$ & $\begin{array}{l}\text { Article } 55 \\
\text { concerning the } \\
\text { quota of } 30 \% \\
\text { of women in } \\
\text { the candidate } \\
\text { list }\end{array}$ & $\begin{array}{l}\text { Article } 245 \\
\text { concerning } \\
\text { women's } \\
\text { representation } \\
\text { of at least } 30 \%\end{array}$ \\
\hline 3 & $\begin{array}{l}\text { Nomination } \\
\text { Method }\end{array}$ & $\begin{array}{l}30 \% \text { quota for } \\
\text { women's } \\
\text { representation in } \\
\text { the preparation of } \\
\text { the legislative } \\
\text { candidate list }\end{array}$ & $\begin{array}{l}55 \text { paragraph (2) } \\
\text { regarding the } \\
\text { zipper system in } \\
\text { compiling a list } \\
\text { of political party } \\
\text { candidates }\end{array}$ & $\begin{array}{l}\text { Article } 56 \\
\text { paragraph } 2 \\
\text { regarding the } \\
\text { zipper system. } \\
\text { Every } 3 \\
\text { prospective } \\
\text { candidates at } \\
\text { least one } \\
\text { woman }\end{array}$ & $\begin{array}{l}\text { Article } 246 \\
\text { paragraph }(2) \\
\text { regarding the } \\
\text { zipper system. } \\
\text { Every } 3 \\
\text { candidates, there } \\
\text { is at least } 1 \\
\text { female } \\
\text { candidate }\end{array}$ \\
\hline 4 & Voting Method & $\begin{array}{l}\text { Parties and } \\
\text { candidates or } \\
\text { parties only }\end{array}$ & $\begin{array}{l}\text { Parties or } \\
\text { candidates }\end{array}$ & $\begin{array}{l}\text { Number or } \\
\text { image of } \\
\text { political } \\
\text { parties and / or } \\
\text { names of } \\
\text { candidates }\end{array}$ & $\begin{array}{l}\text { Number or } \\
\text { image of } \\
\text { political parties } \\
\text { and / or names } \\
\text { of candidates }\end{array}$ \\
\hline 5 & $\begin{array}{l}\text { Elected } \\
\text { candidate } \\
\text { formula }\end{array}$ & $\begin{array}{l}100 \% \text { BPP + } \\
\text { Serial number }\end{array}$ & $\begin{array}{l}30 \% \text { BPP + serial } \\
\text { number (later } \\
\text { changed by } \\
\text { majority vote } \\
\text { referring to the } \\
\text { Decree of the } \\
\text { Constitutional } \\
\text { Court on } \\
\text { December } 26, \\
2008 \text { ) }\end{array}$ & $\begin{array}{l}\text { Based on } \\
\text { majority votes }\end{array}$ & $\begin{array}{l}\text { Based on } \\
\text { majority votes }\end{array}$ \\
\hline
\end{tabular}

Source: Processed from Wardani [3]

The policies above are expected to have an impact on increasing the number of female legislative candidates in the 2004 elections, 2009 elections, 2014 elections and 2019 elections. With the assumption that an increase in the number of women on the candidate list will increase the chances of women candidates being elected in the legislative body both in the DPR and in the DPRD. In addition, the determination of the elected candidates based on the majority of votes is also considered to provide an advantage for female candidates to be elected. Although the struggle for affirmative policies in the administration of elections in Indonesia has started to be stipulated in the form of laws since the 2004 elections, in reality it has not produced significant results in the political representation of women in the legislative body. The problem 
that is still the same in every election implementation is that there are still political parties that have not fulfilled the $30 \%$ quota requirement for women in the preparation of candidates, as well as the percentage of elected female candidates. The problem of not fulfilling the $30 \%$ representation of women is a problem in almost all levels of legislative institutions, both central and regional. In the DPR, the number of female candidates has even fluctuated in the number of elected candidates from the 2004 elections to the 2019 elections. However, they are still unable to fulfill $30 \%$ of women's representation. The fluctuation of elected female candidates in the DPR can be seen in the following table:

Table 2 Comparison of Elected Women DPR Candidates for Women DPR Candidates in the 2004 Election to the 2019 Election

\begin{tabular}{|c|c|c|c|c|c|}
\hline No & Information & 2004 Election & 2009 Election & 2014 Election & $\begin{array}{c}2019 \\
\text { Election } \\
\end{array}$ \\
\hline 1 & $\begin{array}{l}\text { Number of Women } \\
\text { DPR Candidates }\end{array}$ & 2.507 & 3.910 & 2.467 & 3.200 \\
\hline 2 & $\begin{array}{l}\text { Percentage of Female } \\
\text { DPR Candidates }\end{array}$ & $33 \%$ & $34,7 \%$ & $37,33 \%$ & 40,08 \\
\hline 3 & $\begin{array}{l}\text { Number of Elected } \\
\text { Female DPR Candidates }\end{array}$ & 61 & 101 & 79 & 118 \\
\hline 4 & $\begin{array}{l}\text { Percentage of } \% \\
\text { Elected Female DPR } \\
\text { Candidates }\end{array}$ & $11,09 \%$ & $17,86 \%$ & $14,10 \%$ & $20,52 \%$ \\
\hline
\end{tabular}

Source : Processed from Wardani [3]

In table 2 it is known that there was an increase in the number of female DPR candidates from the 2004 Election to the 2009 Election followed by the number of elected female DPR legislative candidates, and vice versa in the 2014 Election the decrease in the number of female DPR candidates was also followed by a decrease in the number of female DPR candidates elected in the 2014 Election and increase again in the 2019 elections. However, the figures and percentages above still show the percentage of women's representation who do not meet the $30 \%$ target in the legislative body. This also occurs in the Provincial DPRDs and Regency / Municipal DPRDs in Indonesia, although there are several regions that are able to meet the 30\% quota for women's representation such as the North Sulawesi Provincial DPRD in the 2014 Election with $31.11 \%$ representation of women and some Regency / City DPRDs. However, it is interesting to trace the political representation of women in the DPRD Kota Tanjungpinang. Since its establishment as an autonomous region in 2002 and becoming the capital of the Riau Islands Province, female candidates elected to the Tanjungpinang City DPRD since the 2004 elections to the 2019 elections have always increased. This significant increase occurred from the 2014 Election to the 2019 Election, as can be seen in the following table: 
Table 3 Elected Female Candidates for DPRD of Tanjungpinang City in the 2014 Election and 2019 Election

\begin{tabular}{cl|cccc|cccc}
\hline \multirow{2}{*}{ No } & \multirow{2}{*}{ Information } & \multicolumn{4}{|c|}{ 2014 Election } & \multicolumn{4}{c}{ 2019 Election } \\
\cline { 3 - 10 } & & $\mathrm{Lk}$ & $\%$ & $\operatorname{Pr}$ & $\%$ & $\mathrm{Lk}$ & $\%$ & $\operatorname{Pr}$ & $\%$ \\
\hline 1 & Number of Candidate & 223 & 62,6 & 133 & 37,4 & 269 & 64,98 & 145 & 35,05 \\
2 & Number of Elected & 22 & 73,33 & 8 & 26,67 & 19 & 63,33 & 11 & 36,67 \\
\hline
\end{tabular}

Source : Processed data from KPU Kota Tanjungpinang. [4]

Table 3 shows that the increase in the number of female DPRD candidates was followed by the electability of female candidates in the Tanjungpinang City DPRD. If traced from the 2004 Election only 1 female candidate was elected to the Tanjungpinang City DPRD, then in the 2009 Election it increased to 4 people, this number continued to increase in the 2014 Election with 8 female candidates elected and in the 2019 Election to 11 people, this number the percentage exceeds $30 \%$ of the quota for women's representation in the DPRD of Tanjungpinang City

\subsection{Theoretical study}

\section{Womens Political Representation}

The concept of women's political representation or women's political representation basically refers to the theory of representative democracy. Anne Phillips is one of the scientists who provide the rationale for the movement of women's representation from the politics of idea to the politics of presence. The meaning contained in the politics of presence here is the demand for equal and fair and equal representation between men and women.[2]

Squires [5] argues for the importance of women's participation in four ways . first, the duties or roles of women themselves. In terms of gender, men and women have different roles and duties. The understanding of the role of each group can only be understood by the group itself, likewise in terms of women's duties, it can only be carried out by women themselves. Second, as one of the values of justice. This means that there must be a balance of representation in quantity between men and women. Third, the interests of women. The different interests of women and men and their understanding of their conditions make it necessary for women's groups to take an active role in the formal political aspects of fighting for women's issues themselves. Fourth, democratic revitalization. Women should play an active role in decisionmaking positions to provide an understanding of differences in interests and acceptance of differences in the public sphere and not only in the domestic environment, that these interests must be fought for and not simply left to other groups with different interests. This value is protected by the values of a democratic country

According to Pitkin, democracy and repression have a complex relationship which he calls problematic. The complexity of the relationship between the concepts of democracy and government as well as political representation will be easy to understand if these concepts are related to one another. The binding components are the concept of election and constituency [6]. The concept of political representation that focuses on elections and formal institutions is conveyed by Pitkin as a 'standard account' representation concept, that there is a relationship between those who are elected and those who elect and elections as an authorization mechanism.

Furthermore, Pitkin also expressed his views on representation, firstly formal representation. This relates to the process before the representation occurs. He saw from the authorization of a person in an institution and accountability related to the ability of constituents 
or voters to make their choices. Second, symbolic representation. This representation is a way of a people's representative to fight for or on behalf of his constituents, this is usually a representation in the form of a symbol that represents his community. Third, descriptive representation. This representation is based on people's representatives who represent their groups because of the same interests to be fought for. Fourth, substantive representation. This is indicated by activities carried out on behalf of the community or group represented so that he fights for the interests he wants to raise.

Meanwhile, Dovi emphasizes elections and explains the concept of political representation that is often associated with democracy. Dovi's views of political representation can be understood in a way to build (1) the legitimacy of democratic institutions, and (2) create institutional incentives for the government to respond to people's aspirations [7] .

\section{The Struggle to Increase Women's Political Representation}

The struggle for women's political representation cannot be separated from the movement for gender equality. This cannot be separated from the view that women's rights are part of human rights. The declaration of human rights (DUHAM) shows a commitment to uphold and protect individual human rights, both men and women. The declaration then became the commitment of all countries in the world by adopting it in the policies of their respective political systems.

The world meeting that discussed women in Beijing in 1995 and produced the Beijing Platform for Action (BPFA), emphasizing gender equality does not mean that women have to be the same as men. But what is meant is equal opportunities in realizing the potential of their human rights so that women contribute to political, economic, social, and cultural development and have the same opportunity to enjoy the results of development [8] . The 1995 BPFA also stated that there are 12 critical areas that are related to women and allow for gender disparities. The twelve critical areas are: (1) women and poverty; (2) education and training for women; (3) women and health; (4) violence against women; (5) women and armed conflict; (6) women and the economy; (7) women in power and decision making; (8) institutional mechanisms for the advancement of women; (9) women's human rights; (10) women and the media; (11) women and the environment; and (12) teenage girls [9] .

The problems related to women mentioned above are very vulnerable if they are not fought for and represented by women themselves because it will cause many problems such as injustice in the law, domestic violence or gender-biased policies. Here the importance of women's representation is not only an idea but also a quantity present in fighting for women's interests. As stated by Nur Iman Subono in the book introduction to Ani Sutjipto and Shelly Adelina that:

"In political science, there are three assumptions that underlie discussions of women and politics. First, politics has different effects on men and women. Second, political processes that have been and are currently in progress have often changed gender relations between men and women. Third, men and women who participate as political subjects actually carry out different political activities." [10]

In other words, politics can never be gender neutral. The tendency so far is that formal politics is often inhabited by the male sex, so that the form, content and ideas of public organizations have a masculine character while women must follow the values characterized by men. In the end, we see politics as a field of study for men while women are only followers. Women are more emphasized on domestic activities, but often lag behind in formal political activities in decision making. Increasing women's political representation is important when policies issued 
are related to women's interests which are sometimes not understood and felt by men. Women's political representation is not just an idea, but presenting women in formal institutions is an imperative to improve.

\section{Methodology}

This paper attempts to explain the phenomenon of women's political representation that occurs in Indonesia, especially in the DPRD of Tanjungpinang City. The approach used is qualitative with a descriptive method because the author tries to describe in-depth the process of women's presence in the legislative body as seen from the results of the 2014 and 2019 elections. Women's representation in the Tanjungpinang City DPRD begins by describing the nomination process and the preparation of prospective candidates in a compiled list by political parties at the Kota Tanjungpinang level.

Furthermore, the authors describe the electability level of female candidates in the DPRD of Tanjungpinang City and explain the origins of the elected candidates and analyze the increase in women's representation by linking it to the Tanjungpinang City environment. Although the author is presented in a qualitative descriptive manner, the Author also uses data in the form of election results and processes the data to be factually analyzed.

\section{Finding and Study}

\subsection{Women's Political Representation in Nominations}

The increase in women's political representation in the DPRD of Tanjungpinang City, as explained in the introduction to this paper, has been demonstrated since this institution existed when Tanjungpinang City became an autonomous region and the capital of the Riau Islands Province in 2002. In the first election as an autonomous region in the Riau Islands in 2004, only 1 female legislative member. This number then increased in the 2009 Election to 4 people, 8 people in the 2014 Election and the 2019 Election, it increased again to 11 people. This increase is significant when seen from the nomination process proposed by political parties at the Tanjungpinang City level. In the 2014 and 2019 elections, the DPRD members of Tanjungpinang City no longer number 25 people like in the 2009 elections. This is due to the increase in the population of Tanjungpinang City until since the 2014 election the number of seats in the DPRD of Tanjungpinang City has become 30 seats. In the preparation of the names of candidates submitted by political parties, it is also adjusted to the maximum number of seats contested and in each electoral district, a different seat size is determined due to population factors in each electoral district.

The electoral district for the DPRD of Tanjungpinang City is divided into three electoral districts. The first electoral districts consist of two districts are the Tanjungpinang Kota District and the West Tanjungpinang District and the second Electoral District is the East Tanjungpinang District and then the third Electoral District is the Bukit Bestari District. In the 2014 Election, there were 12 political parties participating in the election to compete for 30 seats in the DPRD of Tanjungpinang City. The maximum number of candidates from each political party is in accordance with the number of seats contested. The total number of female candidates submitted by political parties and stipulated in the Permanent Candidate List (DCT) in the 2014 General Election totaled 356 candidates with the following distribution: 
Table 4 Number of Women Political Party Candidates for DPRD Tanjungpinang City in the 2014 Election

\begin{tabular}{|c|c|c|c|c|c|c|c|}
\hline \multirow[t]{2}{*}{ No } & \multirow[t]{2}{*}{ Name of Party } & \multirow[t]{2}{*}{ NC } & \multicolumn{4}{|c|}{$\begin{array}{l}\text { Quota of Women Filled by } \\
\text { Political Parties Based on the } \\
\text { Total Number of Candidates }\end{array}$} & \multirow[t]{2}{*}{$\begin{array}{c}\text { Electoral Districts Filled } \\
\text { by Women Political } \\
\text { Party Candidates }\end{array}$} \\
\hline & & & $\mathrm{MC}$ & $\%$ & $\mathrm{FC}$ & $\%$ & \\
\hline 1 & Nasdem & 30 & 18 & 60 & 12 & 40 & 3 \\
\hline 2 & PKB & 26 & 17 & 56,7 & 9 & 34,6 & 3 \\
\hline 3 & PKS & 30 & 18 & 60 & 12 & 40 & 3 \\
\hline 4 & PDI-P & 30 & 19 & 63,3 & 11 & 36,7 & 3 \\
\hline 5 & Golkar & 30 & 19 & 63,3 & 11 & 36,7 & 3 \\
\hline 6 & Gerindra & 30 & 19 & 63,3 & 11 & 36,7 & 3 \\
\hline 7 & Demokrat & 30 & 19 & 63,3 & 11 & 36,7 & 3 \\
\hline 8 & PAN & 30 & 18 & 60 & 12 & 40 & 3 \\
\hline 9 & PPP & 30 & 19 & 63,3 & 11 & 36,7 & 3 \\
\hline 10 & Hanura & 30 & 19 & 63,3 & 11 & 36,7 & 3 \\
\hline 11 & PBB & 30 & 19 & 63,3 & 11 & 36,7 & 3 \\
\hline \multirow[t]{2}{*}{12} & PKPI & 30 & 19 & 63,3 & 11 & 36,7 & 3 \\
\hline & TOTAL & 356 & 223 & 62,6 & 133 & 37,4 & \\
\hline
\end{tabular}

Information : NC (Number of Candidates), MC (Male Candidates), FC (Female Candidates ), and \% (Persentage). The number corresponds to the political party serial number

Source : Data processed from KPU Tanjungpinang City. [4]

In the 2014 Election, 12 political parties nominated candidates for 30 seats for the DPRD of Tanjungpinang City. Data released by the KPU of Tanjungpinang City, these 30 seats were contested by 356 candidates spread across 3 electoral districts. Of the 356 candidates, the number of female candidates is 133 or $37.4 \%$, and 223 male candidates or $62.6 \%$. Overall, this number has met the $30 \%$ quota for women's representation as mandated by UU No. 8 Tahun 2012 in the preparation of prospective candidates. The Nasdem, PKS, and PAN parties were the parties with the highest percentage of the quota for female candidates proposed at $40 \%$. If the comparison is calculated, then 1 seat for DPRD members of Tanjungpinang City is contested by 11 to 12 legislative candidates. In general, women's representation is at $30 \%$ from two sides, are: first, the fulfillment of the quota for women's representation by political parties based on the total number of legislative candidates. In this case, 12 political parties fulfilled these requirements with the lowest proposing for female candidates being PKB, namely 9 female candidates or $34.6 \%$. Second, the fulfillment of women's quota based on electoral districts. The 12 political parties participating in the 2014 General Election for the DPRD of Tanjungpinang City as a whole have also met these provisions, namely in 3 existing electoral districts.

Meanwhile, seen from the number of female legislative candidates in the 2019 Election in the Tanjungpinang City DPRD, it has increased to 414 people. This means that 414 legislative candidates from the 16 political parties participating in the 2019 Election are contested for 30 seats in the Tanjungpinang City DPRD. In addition to the 12 political parties participating in the 2014 Election, 4 new political parties have also competed for seats in the Tanjungpinang City DPRD, namely the Indonesian Change Movement Party (Garuda Party), the Berkarya Party, Indonesia Unity Party (Perindo) and the Indonesian Solidarity Party (PSI). The quota for candidates can be seen as follows: 
Table 5 Number of Women Political Party Candidates for the Tanjungpinang City DPRD in the 2019 Election

\begin{tabular}{clcccccc}
\hline \multirow{2}{*}{ No } & Name of Party & NC & \multicolumn{3}{c}{$\begin{array}{c}\text { Quota of Women Filled by } \\
\text { Political Parties Based on the } \\
\text { Total Number of Candidates }\end{array}$} & $\begin{array}{c}\text { Electoral Districts Filled } \\
\text { by Women Political } \\
\text { Party Candidates }\end{array}$ \\
\cline { 3 - 6 } & & MC & $\%$ & FC & $\%$ & \\
\hline 1 & PKB & 29 & 19 & 65,52 & 10 & 34,48 & 3 \\
2 & Gerindra & 30 & 20 & 66,67 & 10 & 33,33 & 3 \\
3 & PDI-P & 30 & 20 & 66,67 & 10 & 33,33 & 3 \\
4 & Golkar & 30 & 20 & 66,67 & 10 & 33,33 & 3 \\
5 & Nasdem & 30 & 20 & 66,67 & 10 & 33,33 & 3 \\
6 & Garuda Party & 27 & 18 & 66,67 & 9 & 33,33 & 3 \\
7 & Berkarya Party & 17 & 11 & 64,71 & 6 & 35,29 & 2 \\
8 & PKS & 30 & 19 & 63,33 & 11 & 36,67 & 3 \\
9 & Perindo & 16 & 9 & 56,25 & 7 & 43,75 & 3 \\
10 & PPP & 30 & 20 & 66,67 & 10 & 33,33 & 3 \\
11 & PSI & 29 & 19 & 65,52 & 10 & 34,48 & 3 \\
12 & PAN & 30 & 20 & 66,67 & 10 & 33,33 & 3 \\
13 & Hanura & 30 & 20 & 66,67 & 10 & 33,33 & 3 \\
14 & Demokrat & 30 & 19 & 63,33 & 11 & 36,67 & 3 \\
15 & PBB & 20 & 11 & 55 & 9 & 45 & \\
16 & PKPI & 6 & 4 & 66,67 & 2 & 33,33 & \\
& Total & $\mathbf{4 1 4}$ & $\mathbf{2 6 9}$ & $\mathbf{6 4 , 9 8}$ & $\mathbf{1 4 5}$ & $\mathbf{3 5 , 0 2}$ & \\
\hline
\end{tabular}

Information: NC (Number of Candidates), MC (Male Candidates), FC (Female Candidates), and $\%$ (Persentage). The number corresponds to the political party serial number Source: Data Processed from [11]

From table 5 it is known that of the 16 political parties participating in the 2019 Election for the Tanjungpinang City DPRD, there are 414 legislative candidates who are fighting for 30 seats and are still the same as the 2014 Election, spread across three electoral districts. 414 candidates from all political parties, 145 candidates or $35.02 \%$ are women and 269 candidates are male or $64.98 \%$. When viewed from the overall percentage of women candidates for political parties, there was a decrease from $37.4 \%$ to $35.02 \%$. Although in terms of numbers it has increased, in terms of percentage it has decreased. This is due to the addition of 4 new political parties to 16 political parties in the 2019 Election. Overall, this percentage has met the $30 \%$ quota for women with political parties having the highest female representation level are PBB, then the Perindo Party, respectively $45 \%$ and $43.75 \%$. If you calculate the ratio between the number of candidates and the number of seats up for grabs, it means that the competition for 1 seat in the 2019 Election in the Tanjungpinang City DPRD has increased to 13 to 14 candidates for 1 seat. The $30 \%$ quota for women is seen from one side based on the total number of female legislative candidates who are filled with political parties, which has exceeded $35.02 \%$, although the percentage is reduced from the 2014 election. On the other hand, it is seen based on the fulfillment of the quota for women in 3 electoral districts. The Berkarya Party and PKPI are two parties that only meet the quota for women in the two election regions.

Even though the determination of the selected candidates is based on the most votes added to the zipper system by placing 1 female candidate in 3 candidates, the placement of female candidates in the serial number also needs attention. In the 2014 Election, the position of female candidates in the serial number can be seen in the following table: 
Table 6 Serial Number of Women Legislative Candidates for DPRD of Tanjungpinang City in the 2014 election

\begin{tabular}{|c|c|c|c|c|}
\hline No & Name of Party & constituency & $\begin{array}{c}\text { Number of Female } \\
\text { Candidates }\end{array}$ & $\begin{array}{c}\text { Female Candidate } \\
\text { Serial Numbers }\end{array}$ \\
\hline \multirow{3}{*}{1} & \multirow{3}{*}{ Nasdem } & 1 & 5 & $2,4,6,8,9$ \\
\hline & & 2 & 4 & $2,4,6,8$ \\
\hline & & 3 & 3 & $2,4,6$ \\
\hline \multirow{3}{*}{2} & \multirow{3}{*}{ PKB } & 1 & 4 & $3,6,9,11$ \\
\hline & & 2 & 3 & $3,6,9$ \\
\hline & & 3 & 2 & 3,6 \\
\hline \multirow{3}{*}{3} & \multirow{3}{*}{ PKS } & 1 & 4 & $3,6,8,10$ \\
\hline & & 2 & 5 & $1,3,6,8,11$ \\
\hline & & 3 & 3 & $3,6,8$ \\
\hline \multirow{3}{*}{4} & \multirow{3}{*}{ PDI-P } & 1 & 4 & $3,6,9,11$ \\
\hline & & 2 & 4 & $3,5,8,10$ \\
\hline & & 3 & 3 & $3,6,8$ \\
\hline \multirow{3}{*}{5} & \multirow{3}{*}{ Golkar } & 1 & 4 & $2,6,8,10$ \\
\hline & & 2 & 4 & $3,6,9,10$ \\
\hline & & 3 & 3 & $1,2,4$ \\
\hline \multirow{3}{*}{6} & \multirow{3}{*}{ Gerindra } & 1 & 4 & $1,5,9,11$ \\
\hline & & 2 & 4 & $3,6,8,10$ \\
\hline & & 3 & 3 & $3,6,7$ \\
\hline \multirow{3}{*}{7} & \multirow{3}{*}{ Demokrat } & 1 & 4 & $3,6,9,11$ \\
\hline & & 2 & 4 & $3,6,9,10$ \\
\hline & & 3 & 3 & $1,4,8$ \\
\hline \multirow{3}{*}{8} & \multirow{3}{*}{ PAN } & 1 & 4 & $2,6,7,10$ \\
\hline & & 2 & 5 & $2,6,8,9,11$ \\
\hline & & 3 & 3 & $3,5,7$ \\
\hline \multirow{3}{*}{9} & \multirow{3}{*}{ PPP } & 1 & 4 & $1,4,7,10$ \\
\hline & & 2 & 4 & $3,6,8,11$ \\
\hline & & 3 & 3 & $3,6,8$ \\
\hline \multirow{3}{*}{10} & \multirow{3}{*}{ Hanura } & 1 & 4 & $3,6,9,11$ \\
\hline & & 2 & 4 & $1,6,8,11$ \\
\hline & & 3 & 3 & $3,5,9$ \\
\hline \multirow{4}{*}{11} & \multirow{4}{*}{ PBB } & 1 & 4 & $3,6,9,11$ \\
\hline & & 2 & 4 & $3,6,9,10$ \\
\hline & & 3 & 3 & $3,6,7$ \\
\hline & & 1 & 4 & $3,6,8,9$ \\
\hline \multirow[t]{2}{*}{12} & \multirow[t]{2}{*}{ PKPI } & 2 & 4 & $3,5,6,9$ \\
\hline & & 3 & 3 & $3,5,6$ \\
\hline
\end{tabular}

Sumber: Processed data from KPU Tanjungpinang City [4] .

The serial number of female political party candidates in the DPRD of Tanjungpinang City in the 2014 Election and the overall majority in the three electoral districts is filled with serial number 3 . In table 6 it is known that there are 6 political parties that do not exist at all placing female candidates in serial number 1 and more are placed in serial number 3 . Meanwhile, only 6 political parties place female candidates at serial number 1 and each in one electoral district. This means that only $16.67 \%$ of female candidates are in candidate number 1 , while candidate number 2 is also occupied by $16.67 \%$ of female candidates, while candidate number 3 is the majority of women candidates in the nomination list with $66.67 \%$. Meanwhile, in the 2019 
Election, the position of female candidates in the serial number can be seen in the following table:

Table 7 Serial Number of Women Legislative Candidates for DPRD of Tanjungpinang City in the 2019 Election

\begin{tabular}{|c|c|c|c|c|}
\hline No & Name of party & Constituency & $\begin{array}{c}\begin{array}{c}\text { Number of female } \\
\text { candidates }\end{array} \\
\end{array}$ & $\begin{array}{c}\text { Female candidate } \\
\text { serial numbers }\end{array}$ \\
\hline \multirow{3}{*}{1} & \multirow{3}{*}{ PKB } & 1 & 3 & $3,4,8$ \\
\hline & & 2 & 4 & $2,6,8,10$ \\
\hline & & 3 & 3 & $1,4,7$ \\
\hline \multirow{3}{*}{2} & \multirow{3}{*}{ Gerindra } & 1 & 3 & $2,5,8$ \\
\hline & & 2 & 4 & $1,6,9,11$ \\
\hline & & 3 & 3 & $3,6,8$ \\
\hline \multirow{3}{*}{3} & \multirow{4}{*}{ PDI-P } & 1 & 3 & $2,5,8$ \\
\hline & & 2 & 4 & $1,4,7,10$ \\
\hline & & 3 & 3 & $3,5,8$ \\
\hline \multirow{3}{*}{4} & & 1 & 3 & $3,5,7$ \\
\hline & \multirow{2}{*}{ Golkar } & 2 & 4 & $3,6,8,10$ \\
\hline & & 3 & 3 & $2,4,7$ \\
\hline \multirow{4}{*}{5} & \multirow{3}{*}{ Nasdem } & 1 & 3 & $3,4,7$ \\
\hline & & 2 & 4 & $3,5,8,11$ \\
\hline & & 3 & 3 & $3,5,7$ \\
\hline & \multirow{4}{*}{ Garuda Party } & 1 & 3 & $1,4,7$ \\
\hline \multirow[t]{3}{*}{6} & & 2 & 3 & $3,6,9$ \\
\hline & & 3 & 3 & $3,4,7$ \\
\hline & & 1 & 0 & - \\
\hline \multirow[t]{3}{*}{7} & \multirow[t]{2}{*}{ Berkarya Party } & 2 & 4 & $3,5,7,11$ \\
\hline & & 3 & 2 & 1,4 \\
\hline & \multirow{4}{*}{ PKS } & 1 & 4 & $3,5,7,9$ \\
\hline \multirow[t]{3}{*}{8} & & 2 & 4 & $1,6,9,11$ \\
\hline & & 3 & 3 & $3,6,7$ \\
\hline & & 1 & 3 & $3,4,5$ \\
\hline \multirow[t]{3}{*}{9} & \multirow{3}{*}{ Perindo } & 2 & 2 & 1,5 \\
\hline & & 3 & 2 & 1,5 \\
\hline & & 1 & 3 & $1,4,8$ \\
\hline \multirow[t]{3}{*}{10} & \multirow{3}{*}{ PPP } & 2 & 4 & $3,6,9,11$ \\
\hline & & 3 & 3 & $3,6,8$ \\
\hline & & 1 & 3 & $3,6,8$ \\
\hline \multirow[t]{3}{*}{11} & \multirow[t]{3}{*}{ PSI } & 2 & 4 & $2,6,9,12$ \\
\hline & & 3 & 3 & $3,6,7$ \\
\hline & & 1 & 3 & $3,6,9$ \\
\hline \multirow[t]{3}{*}{12} & \multirow[t]{3}{*}{ PAN } & 2 & 4 & $3,6,9,12$ \\
\hline & & 3 & 3 & $3,6,7$ \\
\hline & & 1 & 3 & $2,6,9$ \\
\hline 13 & Hanura & 2 & 4 & $3,6,8,10$ \\
\hline & & 3 & 3 & $3,5,6$ \\
\hline & & 1 & 3 & $1,4,9$ \\
\hline 14 & Demokrat & 2 & 4 & $3,6,9,11$ \\
\hline & & 3 & 4 & $1,3,5,7$ \\
\hline 15 & PBB & 1 & 2 & 3,5 \\
\hline 15 & РВB & 2 & 5 & $3,4,5,6,9$ \\
\hline
\end{tabular}




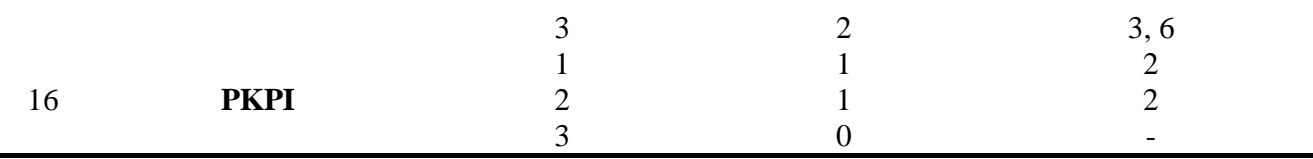

Sumber: Processed data from [11]

From table 7 , it can be seen that there are 7 political parties that do not place female candidates at number 1 . However, there has been an increase compared to the 2014 Election because there are 9 political parties that place their female candidates at serial number 1 . While the Berkarya Party and PKPI only filled their candidacy in two electoral districts. As is the case with the number 3 female candidate in the 2014 Election, in the 2019 Election is also dominated by female candidate number 3 as $56.25 \%$.

\subsection{The Election of Female Candidates}

Female candidates elected in the 2014 and 2019 elections experienced an increase in the number and percentage of women's electability in the DPRD of Tanjungpinang City. In table 3 it can be seen that the increase in the number of female candidates in the 2009 Election from 4 to 8 in the 2014 Election. This Total continued to increase in the 2019 Election to 11 people and women's representation in the DPRD of Tanjungpinang City exceeded the $30 \%$ quota into $36.67 \%$. If you look at the votes acquired and the serial number of the elected female candidates in the DPRD of Tanjungpinang City in the 2014 and 2019 Elections, it can be seen in tables 8 and 9. In the 2014 Election, the electability of women candidates in the DPRD of Tanjungpinang City is described as follows:

Table 8 Result Votes for Elected Women Legislative Candidates for DPRD Tanjungpinang City in the 2014 election

\begin{tabular}{|c|c|c|c|c|c|c|}
\hline No & Party & $\begin{array}{l}\text { Name of Selected } \\
\text { Candidates }\end{array}$ & $\begin{array}{c}\text { Serial } \\
\text { Number of } \\
\text { Selected } \\
\text { Candidates }\end{array}$ & Result Votes & $\begin{array}{c}\text { Origin } \\
\text { of the } \\
\text { electoral } \\
\text { district }\end{array}$ & $\begin{array}{c}\text { Ranking in } \\
\text { Electoral } \\
\text { District }\end{array}$ \\
\hline 1 & PKS & Ismiyati & 1 & 1.206 & 2 & 1 \\
\hline 2 & PDI-P & Rahma & 3 & 2.046 & 2 & 1 \\
\hline 3 & Golkar & $\begin{array}{l}\text { Mimi Betty } \\
\text { Wilingsih }\end{array}$ & 1 & 797 & 3 & 1 \\
\hline 4 & Gerindra & Maiyanti & 11 & 735 & 1 & 1 \\
\hline 5 & Demokrat & Pepy Candra & 1 & 852 & 3 & 1 \\
\hline 6 & PAN & Rika Adrian & 2 & 984 & 2 & 1 \\
\hline 7 & PPP & Rosiani & 1 & 810 & 1 & 1 \\
\hline 8 & Hanura & Reni & 5 & 1.755 & 3 & 1 \\
\hline
\end{tabular}

Source : Decree of the KPU Tanjungpinang Number 29/Kpts/KPU-Kota-031.436741/2014 about The Acquisition of Seats for Political Parties and Elected Candidates for DPRD Members of Tanjungpinang City in 2014-2019 and KPU Tanjungpinang City [4]

From table 8 , it is known that the number of elected female candidates gets the most votes in parties and their electoral districts. Female candidates are elected evenly in three electoral districts, are 2 people in electoral districts 1 and 3 people each in electoral districts 2 and 3 . If you look at the electability of female candidates in the 2014 Election based on serial numbers, 
it shows that the odds are number 1 and 2 to be elected is quite large because $62.5 \%$ of the elected female candidates are in serial numbers 1 and 2 . However, large serial numbers such as serial number 11 have also been successfully elected. This is possible because, in the 2014 Election, the determination of the selected candidates was determined based on the majority of votes. In addition, only 9 were political parties the 12 political parties participating in the 2014 General Election that succeeded in obtaining seats in the DPRD of Tanjungpinang City. Of the 9 political parties that obtained these seats, 8 political parties placed their female representatives in the DPRD of Tanjungpinang City. This means that $88.89 \%$ of the political parties in the DPRD of Tanjungpinang City have female representatives.

Meanwhile in the 2019 General Election, in addition to increasing the number of female candidates also followed by the distribution of female candidates from political parties who obtained seats in the Tanjungpinang City DPRD. Of the 16 political parties participating in the 2019 Election for the election of DRPD members in Tanjungpinang City, only 10 political parties managed to get seats. The 10 political parties that have secured seats in the DPRD of Tanjungpinang City also have female representatives. Data on women's electability in the Tanjungpinang City DPRD in the 2019 Election can be seen in the following table:

Table 9 Elected Female Legislative Candidates for the DPRD of Tanjungpinang City in the 2019 Election

\begin{tabular}{|c|c|c|c|c|c|c|}
\hline No & Party & $\begin{array}{l}\text { Name of Selected } \\
\text { Candidates }\end{array}$ & $\begin{array}{c}\text { Serial } \\
\text { Number of } \\
\text { Selected } \\
\text { Candidates }\end{array}$ & $\begin{array}{c}\text { Vote } \\
\text { Acquisition }\end{array}$ & $\begin{array}{c}\text { Origin } \\
\text { of } \\
\text { constitu } \\
\text { ency }\end{array}$ & $\begin{array}{l}\text { Ranking in } \\
\text { the } \\
\text { constituency }\end{array}$ \\
\hline 1 & PPP & Rosiani & 1 & 966 & 1 & 1 \\
\hline 2 & Hanura & Reni & 2 & 1.803 & 1 & 1 \\
\hline 3 & Partai & Maiyanti & 2 & 863 & 1 & 1 \\
\hline 4 & & $\begin{array}{l}\text { Sri Artha } \\
\text { Sihombing }\end{array}$ & 8 & 1.376 & 1 & 2 \\
\hline 5 & PDI-P & $\begin{array}{l}\text { Hj. Yuniarni } \\
\text { Pustoko Weni, } \\
\text { SH }\end{array}$ & 1 & 1.596 & 2 & 1 \\
\hline 6 & PKB & $\begin{array}{l}\text { Rini Pratiwi, } \\
\text { MM.Pd }\end{array}$ & 2 & 798 & 2 & 1 \\
\hline 7 & PKS & Ismiyati & 1 & 1.746 & 2 & 1 \\
\hline 8 & Demokrat & $\begin{array}{c}\text { Rina Febriani, } \\
\text { SE }\end{array}$ & 9 & 1.541 & 2 & 1 \\
\hline 9 & PAN & Rika Adrian & 9 & 1.018 & 2 & 1 \\
\hline 10 & Golkar & $\begin{array}{l}\text { Mimi Betty } \\
\text { Wilingsih }\end{array}$ & 2 & 1.142 & 3 & 2 \\
\hline 11 & Nasdem & $\begin{array}{c}\text { Ria Ukur Rindu } \\
\text { Tondang }\end{array}$ & 5 & 1.196 & 3 & 2 \\
\hline
\end{tabular}

Source: Decree Number 32 of 2019 about The Determination of The Elected Candidates for DPRD Members of Tanjungpinang City.

The elected female candidates in table 9 show that they came from all political parties that obtained seats in the Tanjungpinang City DPRD and even the PDI-P succeeded in placing 2 female representatives. Of the 11 elected female candidates based on the serial number, it shows that serial numbers 1 and 2 are still the serial numbers that have a greater chance of being 
elected, namely 7 people or $63.64 \%$. Meanwhile, 4 female candidates with serial numbers above 5,8 , and 9 were also successfully elected and 3 of them were elected candidates for the first time. Based on the electoral districts, the number of female candidates elected in constituency 3 is reduced to 2 seats, while the increase in female candidates elected in the electoral district is 2 from 3 seats to 5 seats and in the constituency 1 from 2 seats to 4 seats. Of the 11 elected female candidates, 6 are incumbent members of the Tanjungpinang City DPRD for the 20142019 period and added by 1 member of the Riau Islands Provincial DPRD for the 2014-2019 period and are the wife of the former Tanjungpinang Mayor for the 2013-2018 period, Lis Darmansyah.

\subsection{The Election Base of Female Candidates}

The increase in women's representation that has continued to increase since the 2004 elections shows that the efforts of women legislators to fight for and represent women in the DPRD of Tanjungpinang City are considered successful by constituents. Not only elected female candidates have increased until the 2019 Election exceeds $30 \%$ of the quota for women in the legislature, but it is also followed by the re-election of incumbent members of the legislature in the previous period. In the 2014 election, out of 8 elected female candidates, 3 of them were members of the DPRD of Tanjungpinang City in the 2009-2014 period. This means that 4 members of the legislature in the 2009-2014 period were only 1 person who was not reelected and that was because they did not participate in the candidacy in the 2014 elections. Likewise in the 2019 Election, out of 11 elected female candidates, 6 of them were incumbents in the 2014-2019 period. The success of women politicians in the DPRD of Tanjungpinang City was also followed by the election of a female legislative member from the PDI-P to become Deputy Mayor of Tanjungpinang in the 2018 Regional Head Election. That means, in the 2019 Election only 1 female legislative member was not re-elected in the 2019 Election. However, the addition of women legislators in the 2019 elections reached $62.5 \%$ from the 2014 elections. 
Table 10 The Election Base of Female Candidates in the DPRD of Tanjungpinang City in the 2014 Election and 2019 Election

\begin{tabular}{clcc}
\hline No & \multicolumn{1}{c}{ Election Base } & 2014 Election & 2019 Election \\
\hline 1 & Selected Female Candidates & 8 & 11 \\
& Elective status & & \\
Incumbent & 3 & 6 \\
& Recent Elected & 5 & 5 \\
& Education & 1 & 2 \\
3 & Postgraduate Degrees & 4 & 6 \\
& Bachelor graduate Degree & 3 & 3 \\
& Senior High School & & 1 \\
& Age Vulnerability & 1 & 3 \\
& 21-30 years & 1 & 3 \\
31-40 years & 5 & 4 \\
& 41-50 years & 1 & 7 \\
& 51-60 years & & 1 \\
& Profession & 3 & - \\
& Member of DPRD & - & 3 \\
Lecturer & Entrepreneur & 2 & - \\
& Housewife (IRT) & 1 & \\
& Advocate / Assistant Advocate &
\end{tabular}

Source: Processed data from [4]

The basis of electability for female candidates is not only seen from their representation based on the electoral district, it can also be seen from the period of electability, education level, age-range, and work history as well as the experiences of each elected female candidate. When viewed from the experience of political organizations and community organizations, more than $50 \%$ of women legislators are experienced people. In addition to the 6 incumbent members of the Tanjungpinang City DPRD in the 2014-2019 period, there was also 1 former member of the DPRD of Riau Islands Province who in the 2019-2024 period and the wife of the former Tanjungpinang Mayor for the 2013-2018 period. Yuniarni Pustoko Weni, who comes from PDI-P, is advancing in Tanjungpinang City because in the 2019 Election the husband also advanced in the DPRD of Riau Islands Provincial so that according to the provisions it is not correct for husband and wife to advance in the same area. In the 2019-2024 period, Yuniarni Pustoko Weni also succeeded in becoming the Chairperson of the Tanjungpinang City DPRD.

Meanwhile, from the education sector, the quality of the elected female legislative members in the 2019 Election also varies from high school graduates to postgraduate degrees. Even 2 female legislators who graduated from high school are incumbents. However, 3 newly elected female candidates are housewives (IRT) with S1 educational qualifications. Judging from the age of the elected female legislators in the 2014 and 2019 elections, equity occurs across four age ranges. In the 2014 Election, the most female members of the legislature were in the age range 41-50 years, are 5 people. In the 2019 Election, the legislative members were re-elected, so that there were more female legislators aged 51-60 years and over. In addition, family, relative or husband factors are also one of the reasons for the nomination of women legislative members. Her husband as a political party administrator, members of the DPRD of Riau Islands Provincial, and 2 female candidates in the 2014-2019 period are siblings.

When viewed from the socio-religious background, the 11 female legislators did not only come from the Malay ethnicity. The heterogeneity of the population is also represented in the 
electability of female candidates in the DPRD of Tanjungpinang City. Apart from coming from the Riau Malay tribe, there were 2 elected female legislative members who came from the Medan / Batak tribe, one Javanese and one person who was of Chinese descent. In terms of religion too, although Islam is the majority religion, there are also other religions such as Christianity and Buddhism. So in general, the diversity of the Tanjungpinang people is also represented in the people's representative institutions in the region.

\section{Conclusion}

From the presentation of the increase in women's political representation in the DPRD of Tanjungpinang City in the 2014 Election and 2019 Election, it can be concluded as follows:

a. The greater the number of female candidates on the nomination list so that the greater the return of women to be elected in the legislative body.

b. The incumbent tendency to be re-elected in the DPRD Tanjungpinang City is quite high.

c. The serial number in the nomination list in the DPRD Tanjungpinang City is still a high electability factor.

d. The heterogeneity of society is a supporter of the opportunity and electability factor of women legislators.

\section{References}

[1] S. Rozi, "Mengurangi Dampak Buruk Dominasi Patriarki dalam Politik di Indonesia," Anal. CSIS, vol. 3, p. 369, 2003.

[2] S. Z. Chairiyah, "Perkembangan Keterwakilan Politik Perempuan di DPRD Provinsi Sumatera Barat (Studi Komparatif Kebijakan Affirmative Action Periode Pemilu Legislatif 2004-2014," J. Ina. Kaji. Peremp. Indones. di Drh. Tertinggal, Terdepan, dan Terluar, vol. 2, no. 2, pp. 158-184, 2019.

[3] S. B. E. Wardani, Potret keterpilihan perempuan di legislatif pada Pemilu 2009. Puskapol FISIP UI, 2013.

[4] "Buku Laporan Pelaksanaan Tahapan pemilihan Umum Anggota DPR, DPD dan DPRD Kota Tanjungpinang Tahun 2014.” 2014, [Online]. Available: https://kputanjungpinangkota.com/.

[5] J. Squires, Gender ini Political Theory. Polity Press, 2000.

[6] N. Suseno, Representasi Politik: Perkembangan dari Ajektiva ke Teori. Depok: Puskapol FISIP UI, 2013.

[7] S. Dovi, Political Representation, in Stanford Encyclopedia of Philosoophy. 2011.

[8] T. O. Ihromi, dkk, Penghapusan Diskriminasi Terhadap Wanita. Bandung: PT. Alumni, 2006.

[9] "Kartini Magazine ED 2344 2013.", [Online]. Available: https://ebooks.gramedia.com/magazines/kartini/ed-2344-2013.

[10] A. W. Soetjipto, A. Soetjipto, S. Adelina, and F. B. Timur, Partai politik dan strategi gender separuh hati: perjalanan dari pengalaman tiga partai pemenang pemilu 2009. Parentesis Publisher, 2012. 
[11] A. Sijori, "Daftar Calon Tetap (DCT) 'DPRD TANJUNGPINANG.'2018, [Online]. Available: https://sijorikepri.com/daftar-calon-tetap-dct-dprd-tanjungpinang/. 